\title{
A preliminary overview of community orcharding in the United States
}

\author{
Megan Betz, ${ }^{\text {* }}$ Jacob Mills, ${ }^{\mathrm{b}}$ and James Farmer ${ }^{\mathrm{c}}$ \\ Indiana University-Bloomington \\ favored
}

Submitted August 9, 2016 / Revised November 11 and December 21, 2016 /

Accepted December 22, 2016 / Published online February 13, 2017

Citation: Betz, M., Mills, J., \& Farmer, J. (2017). A preliminary overview of community

orcharding in the United States. Journal of Agriculture, Food Systems, and Community

Development, 7(2), 13-28. http://dx.doi.org/10.5304/jafscd.2017.072.002

Copyright (C) 2017 by New Leaf Associates, Inc.

\begin{abstract}
Community orchards are a type of urban agriculture project bringing fruit- and nut-bearing trees and shrubs to neighborhoods across the U.S. While urban agriculture is receiving substantial attention in food studies literature, community orchards are still largely absent from academic conversations. We conducted a qualitative, inductive survey of community orchard organizations in the U.S. to establish a baseline understanding. This survey was addressed to orchard organizers and focused on two questions. First, what is driving the rise of community orcharding projects in the U.S.?

\footnotetext{
a * Corresponding author: Megan Betz, Department of Geography; Student Building 120; Indiana UniversityBloomington; Bloomington, Indiana 47405 USA; +1-812219-8364; mebetz@indiana.edu

b School of Public Health 133; Indiana UniversityBloomington; Bloomington, Indiana 47405 USA; +1-219-2413849; millsjn@umail.iu.edu

c Department of Recreation, Park, and Tourism Studies, School of Public Health 133; Indiana UniversityBloomington; Bloomington, Indiana 47405 USA; +1-812-8560969; jafarmer@indiana.edu
}

Second, how are the organizations affecting local food systems? Organizations were selected to be recipients of our survey, which garnered a $42.64 \%$ response rate, if they had an Internet presence and active e-mail account; identification of survey participants was Internet-based, and as a result, little is known about orchards that do not have an Internet presence. Findings showed that community orchards are primarily established on public land, often facilitated by municipal parks and recreation departments, and range in size from pocket orchards of just a few trees to multiple acres of diverse planting. Primary motivations for beginning community orchards include concern for the environment, education, and a sense of community. A preliminary understanding of this impact lies at the nexus of these final two motivations. Community orchard organizers predominately reported fruit and nuts produced in the orchard would feed residents in the geographic area

\section{Disclosure and Acknowledgments}

We thank the orchards participating in our survey and the Indiana University School of Public Health-Bloomington for funding in support of the research. 
immediately surrounding the site. This arrangement of public fruit and nut production and volunteer orchard management is leading to a novel form of community development that merits further research.

\section{Keywords}

Urban Agriculture; Local Food; Community Orchards; Community Development

\section{Introduction and Background}

Alternative food projects, which include activities like community-based agriculture and neighborhood foraging or gleaning groups, are capturing national attention as gardens fill decaying urban landscapes and fair trade products line shelves (Goodman \& Goodman, 2009). Such projects are being increasingly regarded as "green infrastructure," a term most commonly associated with storm water management; this language demonstrates a valuation of not only the goods produced by trees and plants, but their services as well (McLain, Poe, Hurley, Lecompte-Mastenbrook, \& Emery, 2012). While this valuation makes projects more interesting to urban planners and public officials, participants in such projects seem drawn to intangible community development aspectsreconnection to each other, to nature, and to their food (Firth, Maye, \& Pearson, 2011; Flachs, 2010; Ohmer, Meadowcroft, Freed, \& Lewis, 2009). However, these potential community-building outcomes have been critiqued for reinforcing the existing corporate food regime, creating alternatives without combating the policies that support the neoliberal marketplace and without overcoming barriers of class and race to create a more inclusive environment (Agyeman \& McEntee, 2014; Guthman, 2008; Holt-Gimenez, 2011; Slocum, 2006).

Understanding the potential communitybuilding outcomes and overcoming these neoliberal tendencies of alternative food projects require an understanding of how minority communities organize. Unlike market logic-based projects that use urban agriculture to teach good food choices, communities of color are using urban agriculture as a tool to reclaim traditional ecological knowledge and combat environmental degradation and enclosures of the commons (Norgaard, Reed, \& Van Horn, 2011). Locally produced food and agriculture are not simply alternatives to the neoliberal marketplace, but offer an alternative form of community structure and governance (Alkon \& Norgaard, 2009; Gottlieb \& Joshi, 2010; Norgaard et al., 2011). Rather than food production as an end, it is a means to empowerment and, more importantly, valuation of a cultural identity.

A new alternative food project is on the rise in the United States. Community orcharding unites volunteers through fruit and nut trees to contribute to their community's food security, knowledge of food production, and environmental health. While a growing literature has traced the history, goals, and motivations of participants in community gardens (Flachs, 2010; Ohmer et al., 2009; Pudup, 2008), the recent wave of community orchards remains largely absent from this literature (Nordahl, 2009). Community gardens are the alternative food project perhaps most widely known. These projects contribute to personal and public health, neighborhood beautification, and a connection to nature (Ohmer et al., 2009; Wakefield, Yeudall, Taron, Reynolds, \& Skinner, 2007); they are also sites for community development (Firth et al., 2011; Saldivar-Tanaka \& Krasny, 2004). Similarities exist between community gardens and community orchards, but conflating the two masks essential differences in style of production and harvest distribution and, more importantly, in the type of community they can develop. Community orcharding is distinct from community gardening in that plantings are largely perennials requiring long-term, rather than singleseason, community and site management (Ames, 2013).

After the initial planting of trees, several years of maintenance are required before trees reach substantial fruit or nut production. This requires having access to volunteers who will stay in one place for several years and who have leisure time that can be committed to nurturing harvests that are years in the future. Further, community orchards are largely planted on public ground and function as an exempted use of public space. These sites allow for the planting of fruit trees otherwise prohibited on public grounds due to the messy, 
hazardous, and aesthetically unpleasing nature of fruit that goes unharvested. Municipalities are beginning to embrace the opportunity that public space offers to improve food security, defined as "daily access to an adequate supply of nutritious, affordable, and safe food" (Nordahl, 2009, p. 5).

Several works have discussed community orchards alongside other urban fruit forestry projects, which also include gleaning and foraging (Ames, 2013; Clark \& Nicholas, 2013; McLain et al., 2012; McLain, Hurley, Emery, \& Poe, 2014; Poe, LeCompte, McLain, \& Hurley, 2014). However, these works take a sustainability science approach that focuses on fruit and nut production and ecosystem services, and do not account for the distinct community development challenges and opportunities that exist in the community orchard. Further, the limited research on community orchards means the community development potential for such sites, and their ability to overcome barriers of race and class facing other alternative food projects, are little understood.

This paper presents the results of a qualitative survey of community orchard organizers across the U.S. Research was conducted with a guiding objective of understanding what activities are conducted in community orchards, learning the stakeholders of community orchards, and gathering demographic data on organizational leadership. This research aims to establish a baseline understanding of what motivates communities to undertake community orcharding, and what the organizers believe these contribute to their communities. The goal of this research is not only to bring orchards into the growing alternative food literature, but also to contribute to the sustainable management of community orchards, aiding the projects in planning for resource longevity and organizational viability.

\section{Methods}

Community orchards were identified through a Google community orcharding group, Facebook groups for community orchard organizers, Internet keyword searches, and an initial list established using Clark and Nicholas's (2013) discussion of urban fruit forestry. Keywords included "community orchard," "food forest," and "urban fruit trees." This means that community orchard organizations identified had an Internet presence and an active e-mail account. As a result, it is unknown how community orchards have been planted by groups who either have limited or no access to the Internet, or who choose not to use the Internet to support their organization; this is discussed further in the limitations section. More than 70 orchards were identified and invited to participate in a webbased questionnaire developed in Qualtrics, online survey software. The survey included four sections: organization origins, size, plantings, location, and goals; organizational structure, decision-making, management practices, and funding; community outreach, information sharing, community partnerships, and harvest distribution; and demographic information (see Appendix).

Communication with potential respondents followed a modified tailored design method (Dillman, Smyth, \& Christian, 2011). This included four separate communications between February 24 and March 23, 2016. Three were e-mails, and a final reminder and invitation took place by phone. As an incentive, those who completed the survey were given a chance to win one of two US $\$ 250$ Visa gift cards for their community orchard project. Of the 68 community orchards whose email addresses received our survey, 36 followed the link; 29 were usable. The remaining seven surveys were looked at, but the survey responses were blank; these surveys were omitted. This resulted in a final response rate of $42.64 \%$. We conducted descriptive analysis with the usable responses received. Responses to open-ended questions were thematically coded (Creswell, 2012). Inductive codes were developed with a hierarchical structure that focused on three themes: environment, education, and a sense of community. Prior to coding, materials were read multiple times to allow themes to emerge from the data. Preliminary themes were used to pull quotations, and quotations were clustered with those with like content to look for keywords. We then searched for alternate versions of these keywords to find additional quotations for further sorting and development of a hierarchy among themes, bearing in mind a primary interest in content related to motivations for starting an orchard and perceived outcomes. 


\section{Results and Discussion}

An understanding of community orchards begins with an understanding of the "community" they create. Part of the community such organizations foster depends on public-nonprofit partnerships. Partnering with local government for land and resources means community orchards are open to all, often from dawn to dusk. These partnerships also result in community orchard sites' position on land unsuitable for development - a fact with mixed implications, as the project offers a way to beautify the space but may also be subject to flooding, poor sunlight, or questionable soil quality. The orchard community appears to be driven by a concern for the environment - and with it the publichealth implications of environmental quality —as well as skill- and knowledge-sharing. While food production is central to the act of community orcharding, affecting community food security may be a secondary outcome, with community development and improving the (social and natural) environment serving as primary outcomes. As we illustrate below, the orchard community includes a sense of care for nonhumans, such as pollinators, and for those who do not participate in orchard care.

\section{Organization Profile}

A majority of community orchards (21 respondents, or $72 \%$ ) have land that was at least partially owned by the city, predominantly facilitated by departments of parks and recreation; other prominent owners were churches (at least seven) and schools (at least five). This adds up to more than 29 , as many community orchard organizations had more than one planting site with a variety of land tenure structures across sites. Ten respondents represented unique community orchards—sites that functioned independently, for example, on church grounds and coordinated by the church. Nineteen respondents were affiliated with organizations that have multiple community orchard planting sites. These 19 organizations fell into two general categories: umbrella orcharding organizations, which work with neighborhoods, schools, and congregations to facilitate or manage orchards, and individual orchard sites, which fit under an umbrella orcharding project with varying degrees of autonomy. While no statistically significant differences emerge in this preliminary analysis, we will explore these varying organizational structures further when data is gathered at the participant level. Umbrella organizations represented collaborations with multiple community partners across the sites that were most dedicated to community orcharding, with multiple sites dedicated to this type of project and with resources to support partners interested in planting fruit and/or nut trees. Organizational structure generally fell into three categories: nonprofits focusing on sustainable food production (two religious organizations are included in this category), neighborhood associations, and local government. Across these categories, community orcharding functioned as one component of how the organizations worked toward their missions, which included a combination of food production, neighborhood revitalization, and community development.

Responding community orchard organizations range in size from 0.12 to 5.5 acres (.048 to 2.25 hectares)_pocket orchards with as few as five trees to larger parks with diverse plantings numbering over 200. Most commonly planted fruits include apples (23), blueberries (20), pears (20), cherries (18), plums (17), raspberries (17), and serviceberries (17). Three respondents explicitly noted that community gardening is a component of their organization, but 22 additional respondents said plantings on site include vegetable, medicinal herb, or flower gardens. Planting decisions are based on, as one respondent stated, "what our gardeners and neighbors want to eat." However, the survey failed to gather clear data on how input from the community is gathered to determine what they want to eat. Respondents said organizational leadership (83\%) and community members (86\%) both participate in determining what is planted.

Site selection, in many ways, reflects the goals of community orcharding discussed by the respondents. As previously noted, many sites partner with public agencies and therefore are located within public parks. The city agency grants permission to plant in spaces described as "vacant," "unbuildable," or "flood prone." Other sites were described as "informal dumps," "trashed freeways," and in states of "disrepair." The 
community orchards' position within public parks and on otherwise unwanted public ground affected not only the size but also the way in which the site was accessed. Twenty-five respondents listed "dawn to dusk" or comparable parks hours as the times during which the community orchard is open to the public. Organizations with more agency in site selection still maintained these hours, but were able to be more accessible to those in need beyond having flexible hours. They could position themselves in neighborhoods where need was highest, rather than being at the will of the municipality and receiving a parcel of land ideal for neither their target population nor agricultural production. Environmental factors like soil conditions, sunlight, and water availability were considered where possible, as were human factors, such as high-traffic areas and a desire within the neighborhood to have green space and food production.

Limited agency in site selection and ambiguity of land tenure has had a substantive impact on the history of community gardens (Balmer et al., 2005; Domene \& Sauri, 2007; Eizenberg, 2012; Emmett, 2011), and community orchards may face the same risks. Eight respondents (27\%) said their organization received all its funding from one source (grants, community fundraising, or local government); sales of merchandise and produce played a very minor role in fundraising across participants. While this dependence on a small pool of resources reflects the charitable nature of the organizations, it may affect their financial viability over the long term.

\section{Participant Profile}

The survey asked organizers and leaders of community orchards to discuss three aspects of community orchard projects: the organization's origins (location, partnerships, goals), organizational structure (decisionmaking, agricultural practice, funding), and community outreach (site accessibility, outreach, harvest distribution). While the geographic spread of respondents was considerable (see Figure 1), those in leadership positions reflected the core critique of alternative food movement projects: white, college-educated, and female. Alternative food projects have been criticized for prioritizing "good" foods and choices, but those foods and choices coded as "good" are also predominantly foods and choices coded as white and easiest to make in whitewashed spaces (Delind, 2011; Farmer, Chancellor,

Robinson, West, \& Weddell, 2014). A majority $(96 \%)$ of respondents identified as white, and $48 \%$ of those who provided their annual household income earned over US $\$ 50,000$. Further, $45 \%$ were college graduates; an additional $48 \%$ held postgraduate a degree; and 64\% identified as female. This alignment contrasts with national census averages, where $63 \%$ identified as white and $53.25 \%$ of households earned above US $\$ 50,000$ annually (U.S. Census Bureau, 2014). The national averages for educational attainment are $18.7 \%$ having bachelor's degrees and $11.4 \%$ having postgraduate degrees (U.S. Census Bureau, 2014). It should be noted here, however, that this bias may be partially the result of method used, as white, affluent city-dwellers are also the most likely to have Internet access and disposable time to commit to responding (Perrin \& Duggan, 2015).
Figure 1. Map of Orchards Surveyed Nationwide. Larger dots indicate higher concentrations of orchards.

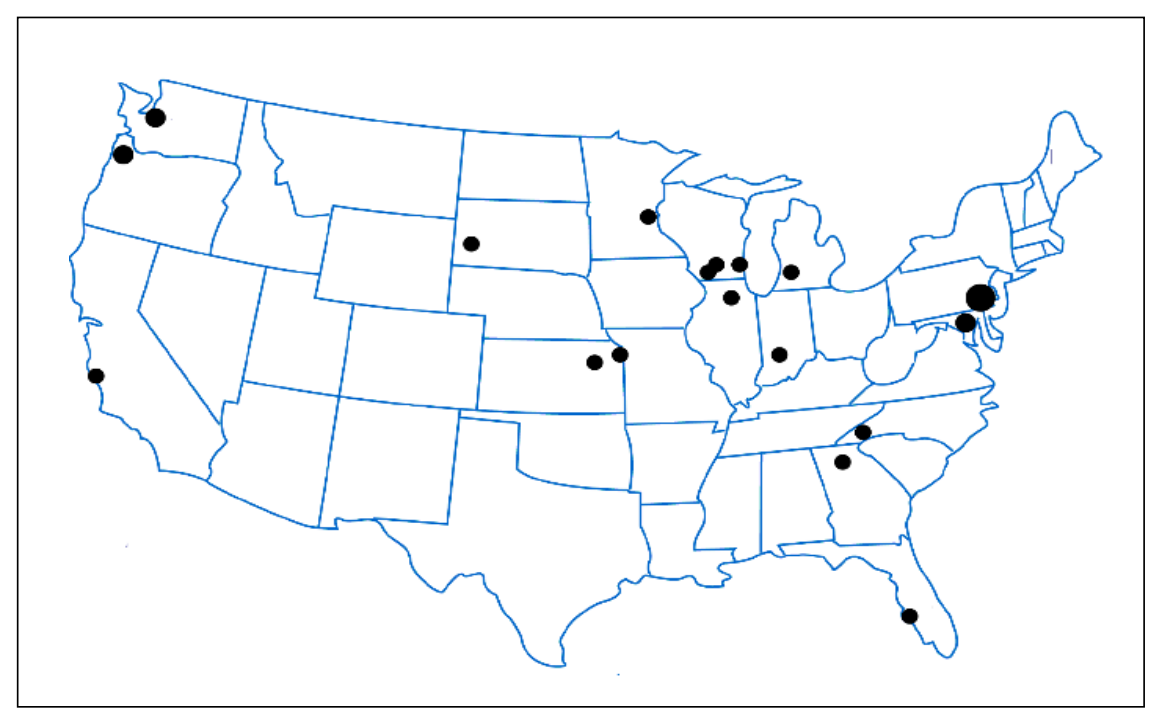


Before claims can be made regarding community orchards further pushing whitewashed "good foods" onto communities, we must gather demographic information on the communities they serve and what the communities desire, beginning with those who participate directly in the community orchard project compared first with the community more broadly and second with the target populations the organization aims to serve.

\section{Drivers in Community Orchard Establishment and Organization}

Our first research question was, "What is driving the rise of community orcharding projects in the U.S.?" Three themes emerged as motivations for community orcharding: concern for the environment, education, and a sense of community.

The motivation concern for the environment manifested in terms like "natural," "native," "pollinators," and "restoration." For example, one respondent said the goal of their community orchard was to "promote community orchards [and] demo organic methods of site remediation (previously had "invasive" blackberry on site)." Permaculture was claimed to be the most prominent orchard management style, with 13 respondents stating this best reflected their practices; others largely described their management style as sustainable or organic. It is worth noting that no respondent described management practices as conventional. Restoration of more diverse habitats and support for pollinators were common concerns when determining what should be planted on site. Five respondents discussed selecting native plants. Many of these plantings have edible components but are not typically planted in an orchard setting, including crabapples, pawpaws, and shellbark hickory. Others selected native plants to support pollinator habitats and, as one respondent stated, "extend the forage season and offer forage for a diverse range of pollinators" such as native mason bees. Participating in urban native restoration activities was a part of the community orchard's activities for 10 respondents; these activities include educating residents about the benefits and uses of native plants. Such activities may contribute to the community development and connectedness that alternative food projects aim to create. For example, one respondent said their community orchard aimed to "reintroduce our urban/suburban population to the native fruits and nuts of our region that can be grown with very few chemical inputs."

The motivation education manifested in terms like "educate," "educational," and "demonstrate." Educating the community was listed as an organizational goal for $90 \%$ of respondents. Topics of education included how to care for fruit and nut trees, when and how to harvest, and how to support native plants and pollinators. Many of the orchards host educational workshops and classes or have educational components at workdays; educational outcomes included sharing orcharding skills, mentioned by $72 \%$ of respondents. Sharing such skills has the potential to extend the impact of community orcharding beyond the primary site, so that community members can plant fruit and nut trees at home; this may magnify the impact of community orcharding on the local community.

The motivation sense of community manifested in terms like "community," "neighbor," "engage," and "share." This concept was closely tied to the motivation education. For example, one respondent stated, "As the orchard matures, we'll use the site for community education about perennial native food plants, planting, pruning, harvesting, and food preservation." Such statements lead us to believe that improving food security may function as a secondary outcome of the site; this is discussed further below. Of primary concern for respondents was a sense of care and trust, manifesting in the hours the site is open to the public and in how respondents discuss theft and vandalism. While concern over vandalism due to the public nature of the space was mentioned regularly, theft was far less of a concern. Even vandalism was discussed more as a misunderstanding of fruit and nut trees and orchard care than malicious behavior. Respondents generally argued that the fruit and/or nuts were open for the public and that rather than theft or vandalism, the greatest risk to the trees was a lack of knowledge on how to tend and harvest from the trees. One respondent described such damage: "Children have picked off all the green peaches, apples [before they are ripe] until the trees [are] big enough [and the apples are out of their 
reach]; lawnmowers and overeager weed whackers have mown down the berry bushes repeatedly." Educational program- ming was seen as a way to reduce instances of unintentional damage to trees. Three quotations demonstrate well the sentiment of using community education to protect the trees and having the harvest reach its intended audience:

Frankly, I expect the critters will harvest the produce before the people have a chance to. My objective is to show people alternatives to planting labor, space, and managementintensive nonnative fruit trees in their home foodscapes.

Ongoing community building, educational programming, and organizing is the number one way to prevent vandalism, though we often say, "You can't steal free fruit!"

The orchard is open to all at any time. If there are items to be harvested, anyone can go in and harvest.

\section{Community Orchards and the Local Food System} Our second research question was, "How are the organizations impacting local food systems?" Coding terms such as "local," "health," "healthy," and "food" were used to explore how community orchards work within their local food systems. Terms used to explore the impact on the local food system are distinct from ideas of food insecurity or social injustice, instead focusing on overall food production regardless of the socioeconomic and nutritional status of the consumer. While $76 \%$ of respondents listed increasing food security as a goal of their organization, attempts to pull together excerpts on food security failed. In fact, the term "food security" appears just once, and "food desert" only three times. Terms like "access," "nutrition," and "poverty" were used minimally. Five respondents mentioned donating a portion of produce to food pantries, meaning the community orchard is affecting food insecurity indirectly, and those most in need of fresh produce may not be participating in the projects. Further research will show if this is because such themes are implicit in conversations about education and the environ- ment, or if improving food security is, in fact, a secondary outcome of community orcharding.

A preliminary understanding of the impact community orchards have on the local food system lies at the nexus of education and developing a sense of community. When asked whom the community orchard served, $83 \%$ of respondents said the site would feed residents of the geographic area immediately surrounding the site. Remaining respondents served "anyone who participates" in aspects of community orcharding or members of a previously established community (a congregation or preexisting community garden on the site). In all cases, the sense of community motivation is attached to how respondents articulate community orchards' potential impact on the local food system. While for a few sites this is about overcoming socioeconomic barriers, for most the impact stemmed from, as one respondent stated, "giving youth experience growing food" and "sharing healthy food in neighborhood." Another telling example stated the orchards are abundant, "giving healthy food and happiness to many people."

We anticipated "local" emerging in responses as it relates to food production; however, the term instead was one of the key words describing governance and organizational structure. Local governments own the land and function as community partners for $72 \%$ of respondents. In eight cases, local government helped determine what was planted on site. Other local stakeholders including extension agencies, nurseries, and gardening and orcharding experts were cited as sources of skills, knowledge, and other resources. The projects are working to increase access to healthy food, but whether such efforts reach those currently without access or who identify as food insecure is unclear.

Fourteen respondents $(48 \%)$ indicated that they are currently able to distribute harvest, while $15(52 \%)$ have yet to reach the distribution phase. This speaks to the relative youth of community orchard projects in the U.S., as many sites do not yet have mature trees producing substantive harvests. Of those orchards that have reached the distribution phase, four main means for distribution were reported: open harvest or gleaning by neighbors, community members, or passersby (4); distribution among volunteers (7); donations to 
food banks or similar (5); and sales at farmers markets, stands, and carts (5). These methods have varying effects on community development and food security claims.

\section{Limitations and Future Directions}

The limitations of this research offer several opportunities for further study. First, the sample is inherently skewed to community orchards with a web presence, which tends to highlight more affluent urban and white populations (Perrin \& Duggan, 2015). Additionally, some community orchards we may have missed through our solicitation method include those organized by primary and secondary schools; those managed by community centers or churches and serving closed communities, which therefore have limited need for web presence or outreach; those that serve communities with low interest in publicizing their site on the web, such as minority communities protecting their efforts from co-optation; those in communities with limited Internet access, such as those with low incomes; and populations not comfortable using contemporary communication technologies, such as senior citizens or those with antiestablishment political leanings. This may contribute to the lack of diversity among community orchard leadership found among respondents. Second, a sample size of 29 limits the degree to which these results could be seen as representative and the type of data analysis that could be performed. With fewer than 75 community orchards identified nationwide, even a $100 \%$ response rate would not have resulted in a large enough sample size for regression analysis. To overcome this limited sample size and gain a deeper understanding of the community orcharding movement in the U.S., more research should be conducted at the participant level. This allows for a broader sampling, a more accurate picture of whom the organization reaches, and an understanding of how the organization functions "on the ground" rather than in institutional discussion. Finally, much of the community orcharding experience is missed if survey research is the only method used. Expanding to a mixed-methods approach would widen the types of research questions that could be asked. Being "on the ground" in the orchard is an essential next step to understanding motivations for community orcharding and the ways community orchards can impact local food systems.

Future research requires gaining a broader view of participation in community orchards throughout the U.S. A second phase of survey research was attempted, to enable comparison between those who participate solely in community orcharding and those who lead such projects. Unfortunately, the research resulted in a low response rate that prohibited representative statistical analysis or comparison between the two perspectives. The use of surveys as a method with this population should be reconsidered. Future research will also include mixed-method case study research, which will allow for an on-the-ground, embodied understanding of how the community orchard organization engages with those it aims to serve, its actual participants, the surrounding community, and those who identify as food insecure. This research model will provide a deeper understanding of how community orchards engage with ideas of food security and how the practice of communal food production is informed by, and in turn informs how, participants think about their local food system. While contributing to the local foodshed may be an implicit part of community orcharding practice, in that more food is produced and distributed locally, this does not mean that the fruit and nuts produced are contributing to organizational outcomes or to food security more broadly. Making these claims requires evaluating the mission of the organization in relation to institutional practice, as well as comparing the organization's participants, harvest recipients, and the demographics of the community.

\section{Recommendations for Community Orchardists and Their Partners}

One of the greatest challenges community orchards may face is serving those who are food insecure and creating a more just, diverse food system when limited diversity exists in organizational leadership. Those most likely to be food insecure are also most likely to have limited leisure time to dedicate to volunteer activities (Miewald \& McCann, 2013). Means of meaningfully incentivizing work with the orchard may allow these individual to participate. 
Examples may include making paid internships available; working with high school, community college, and university programs to help students earn school credit for their work; or creating more structured professional development components, such as funding board of directors certification programs. These activities would require further fundraising but could easily framed as within the scope and mission of the organization, contributing to antiracist organizational governance (Slocum, 2006). This is an imperative step for community orchards, whose partnerships with municipalities result in plantings on urban green spaces. The tree canopy in urban green space is least dense in neighborhoods of color, and communities of color also have less access to public parks (Heynen, Perkins, \& Roy, 2006; Wolch, Wilson, \& Fehrenbach, 2005). Practicing antiracism may include, for instance, actively seeking coalitions with communities of color to reclaim land for green space or repopulating the canopy.

Developing partnerships with cooperative extension agencies may assist community orchards in several capacities. First, as several respondents described, extension agencies are sources of expertise in place to serve the public. Their knowledge of local species can help community orchards identify plants growing on site, connecting the organizations to Master Gardener volunteers, and offering resources for selecting plants that could thrive in the local environment. Second, extension agencies offer a unique opportunity to reach one of the community orchard's target demographics. Extension agencies, which provide resources through the land-grant university system, offer the Supplemental Nutrition Assistance Program Education Program (SNAP-Ed). In addition to offering opportunities for nutrition and food access programming, working with extension agencies can provide a way to connect with SNAP recipients and enable community orchards to serve one of their target demographics.

Lasting partnerships may play a key role in the long-term viability of community orchard management from an organizational perspective.

Responses show a lack of diversity in fundraising portfolios that could put the organizations' operations at risk in future years. This makes a wide volunteer base essential, both to support the organization in finding new funding sources and to continue labor at the orchard site. Partnerships can increase the number of volunteers and funding sources community orchard organizations have at their disposal, and also offer an opportunity to work actively to increase diversity within their organization so that those they aim to serve have an active role in shaping the organization.

\section{Conclusions}

Alternative food projects are being critiqued for reinforcing white, affluent spaces of "good" food and reinforcing a choice-based, neoliberal ideology in place of food system reform (Agyeman \& McEntee, 2014; Guthman, 2008). By prioritizing individual choice, critics argue, other forms of community development are overlooked. Depending on distribution plans, organizational goals, and who can access and participate in orcharding efforts, community orchards may be subject to similar critiques. While demographic information gathered from community orchard organizers showed the organizations may indeed be sites where whiteness and affluence are performed, this must be explored further by looking at the locations of the orchards within their community and the demographics of those who participate in the community orcharding. The variety of distribution methods used and the goals beyond fruit and nut production, such as community building and orcharding education, discussed by our respondents demonstrate that food security and teaching individuals to select "good" foods are not the primary concern of community orchards in the U.S. Instead, the organizations are emphasizing the skills of fruit and nut production and restoration of the local environment. Therefore, the potential outcomes and outputs of community orchards may be distinct from those of other alternative food projects and require different questions to better understand the communities being built.

\section{References}

Agyeman, J., \& McEntee, J. (2014). Moving the field of food justice forward through the lens of urban political ecology. Geography Compass, 8(3), 211-220. http://dx.doi.org/10.1111/gec3.12122 
Alkon, A. H., \& Norgaard, K. M. (2009). Breaking the food chains: An investigation of food justice activism. Sociological Inquiry, 79(3), 289-305. https://doi.org/10.1111/j.1475-682X.2009.00291.x

Ames, G. K. (2013). Community orchards. Retrieved from the National Sustainable Agriculture Information Service website: https://attra.ncat.org/attrapub/download.php?id=441

Balmer, K., Gill, J., Kaplinger, H., Miller, J., Peterson, M., Rhoads, A.,...Wall, T. (2005). The diggable city: Making urban agriculture a planning priority (Unpublished master's dissertation). Portland State University, Portland, Oregon.

Clark, K. H., \& Nicholas, K. A. (2013). Introducing urban food forestry: A multifunctional approach to increase food security and provide ecosystem services. Landscape Ecology, 28(9), 1649-1669. http://dx.doi.org/10.1007/s10980-013-9903-z

Creswell, J. W. (2012). Qualitative inquiry and research design: Choosing among five approaches (3rd ed.). New York: Sage Publications.

DeLind, L. B. (2011). Are local food and the local food movement taking us where we want to go? Or are we hitching our wagons to the wrong stars? Agriculture and Human Values, 28(2), 273-283. http://dx.doi.org/10.1007/s10460-010-9263-0

Dillman, D. A., Smyth, J. D., \& Christian, L. M. (2011). Internet, mail, and mixed-mode surveys: The tailored design method (3rd ed.). Hoboken, New Jersey: Wiley \& Sons.

Domene, E., \& Saurí, D. (2007). Urbanization and classproduced natures: Vegetable gardens in the Barcelona Metropolitan Region. Geoforum, 38(2), 287-298.

https://doi.org/10.1016/j.geoforum.2006.03.004

Eizenberg, E. (2012). Actually existing commons: Three moments of space of community gardens in New York City. Antipode, 44(3), 764-782. https://doi.org/10.1111/j.1467-8330.2011.00892.x

Emmett, R. (2011). Community gardens, ghetto pastoral, and environmental justice. Interdisciplinary Studies in Literature and Environment, 18(1), 67-86. https://doi.org/10.1093/isle/isq127

Farmer, J. R., Chancellor, C., Robinson, J. M., West, S., \& Weddell, M. (2014). Agrileisure: Farmers’ markets, CSAs, and the privilege in eating local. Journal of Leisure Research, 46(3), 313-328.
Firth, C., Maye, D., \& Pearson, D. (2011). Developing "community" in community gardens. Local Environment, 16(6), 555-568. http://dx.doi.org/10.1080/13549839.2011.586025

Flachs, A. (2010). Food for thought: The social impact of community gardens in the greater Cleveland area. Electronic Green Journal, 1(30). Retrieved from https://escholarship.org/uc/item/6bh7j4z4

Goodman, D. K., \& Goodman, M. (2009). Food networks, alternative. International Encyclopedia of Human Geography, 3, 208-220. https://doi.org/10. 1016/B978-008044910-4.00889-0

Gottlieb, R., \& Joshi, A. (2010). Food justice. Cambridge, Massachusetts: The MIT Press.

Guthman, J. (2008). Bringing good food to others: Investigating the subjects of alternative food practice. Cultural Geographies, 15(4), 431-447. http://dx.doi.org/10.1177/1474474008094315

Heynen, N., Perkins, H. A., \& Roy, P. (2006). The political ecology of uneven urban green space: The impact of political economy on race and ethnicity in producing environmental inequality in Milwaukee. Urban Affairs Review, 42(1), 3-25. http://dx.doi.org/10.1177/1078087406290729

Holt-Giménez, E. (2011). Food security, food justice, or food sovereignty?: Crises, food movements, and regime change. In A. H. Alkon, \& J. Agyeman (Eds.), Cultivating food justice: Race, class, and sustainability (pp. 309-330). Cambridge, Massachusetts: The MIT Press.

Miewald, C., \& McCann, E. (2014). Foodscapes and the geographies of poverty: Sustenance, strategy, and politics in an urban neighborhood. Antipode, 46(2), 537-556. https://doi.org/10.1111/anti.12057

McLain, R. J., Hurley, P. T., Emery, M. R., \& Poe, M. R. (2014). Gathering "wild" food in the city:

Rethinking the role of foraging in urban ecosystem planning and management. Local Environment, 19(2), 220-240. http://dx.doi.org/10.1080/13549839.2013.841659

McLain, R., Poe, M., Hurley, P. T., LecompteMastenbrook, J., \& Emery, M. R. (2012). Producing edible landscapes in Seattle's urban forest. Urban Forestry \& Urban Greening, 11(2), 187-194. http://dx.doi.org/10.1016/j.ufug.2011.12.002

Nordahl, D. (2009). Public produce: The new urban agriculture. Washington, DC: Island Press. 
Norgaard, K. M., Reed, R., \& Van Horn, C. (2011). A continuing legacy: Institutional racism, hunger, and nutritional justice. In A. H. Alkon, \& J. Agyeman (Eds.), Cultivating food justice: Race, class, and sustainability (pp. 23-46). Cambridge, Massachusetts: The MIT Press.

Ohmer, M. L., Meadowcroft, P., Freed, K., \& Lewis, E. (2009). Community gardening and community development: Individual, social and community benefits of a community conservation program. Journal of Community Practice, 17(4), 377-399. http://dx.doi.org/10.1080/10705420903299961

Perrin, A., \& Duggan, M. (2015). Americans' internet access: 2000-2015. Retrieved from http://www.pewinternet.org/2015/06/26/ americans-internet-access-2000-2015/

Poe, M. R., LeCompte, J., McLain, R., \& Hurley, P. (2014). Urban foraging and the relational ecologies of belonging. Social \& Cultural Geography, 15(8), 901-919. http://dx.doi.org/10.1080/14649365.2014.908232

Pudup, M. B. (2008). It takes a garden: Cultivating citizen-subjects in organized garden projects. Geoforum, 39(3), 1228-1240. http://dx.doi.org/10.1016/i.geoforum.2007.06.012
Saldivar-Tanaka, L., \& Krasny, M. E. (2004). Culturing community development, neighborhood open space, and civic agriculture: The case of Latino community gardens in New York City. Agriculture and Human V alues, 21(4), 399-412. http://dx.doi.org/10.1007/s10460-003-1248-9

Slocum, R. (2006). Anti-racist practice and the work of community food organizations. Antipode, 38(2), 327-349. http://dx.doi.org/10.1111/j.14678330.2006.00582.x

U.S. Census Bureau. (2014). American community survey 1-year estimates [Table]. Retrieved from http:// factfinder.census.gov/faces/tableservices/ jsf/pages/productview.xhtml?pid=ACS_14_1YR S0201\&prodType $=$ table

Wakefield, S., Yeudall, F., Taron, C., Reynolds, J., \& Skinner, A. (2007). Growing urban health: Community gardening in South-East Toronto. Health Promotion International, 22(2), 92-101. http://dx.doi.org/10.1093/heapro/dam001

Wolch, J., Wilson, J. P., \& Fehrenbach, J. (2005). Parks and park funding in Los Angeles: An equitymapping analysis. Urban Geography, 26(1), 4-35. http://dx.doi.org/10.2747/0272-3638.26.1.4 


\section{Appendix. Online Questionnaire Distributed to Community Orchard Organizers}

Thank you for participating in this survey to help us understand communities' motivations for undertaking community orcharding projects. The questionnaire will take 15 to 20 minutes to complete. All participants must be at least 18 years old. If you are younger than 18 , we apologize for taking your time. This survey is completely voluntary, and you may choose to discontinue your participation at any time during the survey. The survey is anonymous, and your name will never be attached to the answers that you provide. If you have any questions, please do not hesitate to send an e-mail to [Author's e-mail removed]. Thank you for sharing your time and experience.

As an incentive for completing our survey, your community orchard will have a chance to win one of two $\$ 250$ Visa gift cards. To be eligible, you must complete the full survey. To begin the survey, click next.

\section{PART I: ORGANIZATION'S ORIGINS}

1. What is the name of your organization?

2. What is the name of the community orchard site? (Please answer all remaining questions considering only this orchard site.)

3. Are you an organization that has only one site or multiple sites?
1 single site
Multiple sites

4. What is the total size of the planting site(s) in acres?

5. The plantings are located in $a[n] \ldots$

Urban area

Suburban area

Rural area

Combination of setting types

6. How were these sites selected?

7. Who owns the land on which the plantings are located? (Check all that apply.)

Local government (Please name department)

Private land owners

Volunteers Community members

Nonprofit organization (Please name organization)

Other (Please describe)

8. Do the private landowners attend or participate in orchard labor or events?

Yes

No

9. Please check all orchard crops planted on your site.

\begin{tabular}{|l|l|l|l|}
\hline Apples & Citrus & Jujubes & Plums \\
Apricots & Elderberries & Kiwis & Raspberries \\
Blackberries & Figs & Peaches & Serviceberries \\
Blueberries & Hardy kiwis & Pears & Strawberries \\
Cherries & Hazelnuts & Persimmons & Other (Please list) \\
\hline
\end{tabular}


10. Are there additional plantings on site (culinary or medicinal herbs, flowers, vegetables)?

11. Which of the following best describe the site's goals? (Check all that apply.)

Increase food security

Increase ecosystem services

Share orcharding skills

Increase biodiversity of the community

Build a sense of community

Educate the community

Other (Please describe)

\section{PART II: ORGANIZATIONAL STRUCTURE}

12. Which of the following groups helped determine what has been planted on site? (Check boxes for all groups that participated.)

Organization leadership

Extension agency

Board of directors

Local governments

Volunteers

Community members

Other (Please describe)

13. Will the same stakeholders determine future plantings?

Yes

No

Unsure

14. What is the single best description for the orchard's management practices? (Select one.)

Sustainable

Permaculture

Organic

Beyond organic

Conventional

Blend of organic and conventional

Other (Please describe)

15. Is your orchard USDA-certified organic?

Yes

No

16. What are the orchard's sources of funding? (Total should sum up to $100 \%$.)

Government (Please describe) $\%$

Fundraising within the community $\%$

Grants $\%$

Sale of Merchandise (Please describe, for example t-shirts or mugs)

Sale of produce (Please describe, for example apples or honey) Other (Please Describe) $\%$

Total

$\%$ 
PART III: COMMUNITY OUTREACH

17. When is the site open to the public? (Please list hours, for example 8:00 AM 8:00 PM.)

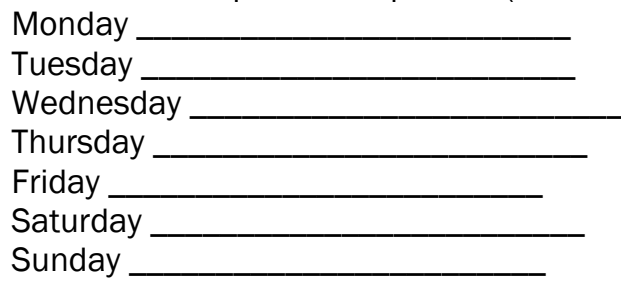

18. How do people learn the rules of the site?

19. How is information shared with volunteers between workdays? (Check all that apply.)

E-Mail

E-Mail newsletter Phone

Twitter

Facebook

Word of mouth

Other social media

Print materials

Other

20. How is information shared with the public (nonvolunteers) between workdays? (Check all that apply.)

E-Mail

E-Mail newsletter

Phone

Twitter

Facebook

Word of mouth

Other social media

Print materials

Other

21. How many people receive your email newsletter?

22. On average, how many events do you host per month?

23. How many individuals volunteer with the organization?

24. Of this number, how many volunteers attend at least one event per month?

25. Does the orchard have a relationship with the county extension agency?

Yes

No

26. Please describe this relationship.

27. Does the orchard primarily serve the people in the neighborhood(s) immediately surrounding the site?

Yes

No

28. Whom does the orchard serve?

29. Is the site currently distributing harvests?

Yes

No 
30. What is the current distribution plan?

31. Please describe any challenges your orchard has experienced with site management and distribution. For example, how does the community orchard anticipate dealing with theft, vandalism, or inappropriate harvesting?

32. Please indicate the extent to which the community orchard's activities extend beyond its designated fruit trees/orchard sites.

\begin{tabular}{|l|l|l|l|l|l|}
\hline & $\begin{array}{c}\text { Not Planned / } \\
\text { No Intention }\end{array}$ & Planned & In Process & $\begin{array}{c}\text { Completed or } \\
\text { Perpetual }\end{array}$ & Not Applicable \\
$\begin{array}{l}\text { Participation in } \\
\text { a planting/ } \\
\text { urban greening } \\
\text { nonprofit }\end{array}$ & & & & & \\
$\begin{array}{l}\text { Participation in } \\
\text { neighborhood } \\
\text { street tree } \\
\text { planting project }\end{array}$ & & & & & \\
\hline $\begin{array}{l}\text { Participation in } \\
\text { state-level } \\
\text { activities in } \\
\text { urban forestry }\end{array}$ & & & & & \\
\hline $\begin{array}{l}\text { Participation in } \\
\text { urban native } \\
\text { restoration } \\
\text { activities }\end{array}$ & & & & & \\
\hline $\begin{array}{l}\text { Engagement } \\
\text { with municipal } \\
\text { agencies to } \\
\text { direct local } \\
\text { policy }\end{array}$ & & & & & \\
Other & & & & & \\
& & & & & \\
\hline
\end{tabular}

\section{PART IV: DEMOGRAPHICS}

33. What is your title with the organization?

34. Is this a paid position?

35. If you have another occupation, what is it?

36. With which gender do you most identify?

Male

Female

Other 
37. What is your age?

38. Are you of Hispanic, Latino or Spanish origin? No, not of Hispanic, Latino, or Spanish origin

Yes, Mexican, Mexican Americano, Chicano

Yes, Puerto Rican

Yes, Cuban

Yes, another Hispanic, Latino, or Spanish origin (Please describe)

39. What is your race or origin? Check all that apply.

White

Black or African American

American Indian or Alaska Native Asian

Native Hawaiian or Pacific Islander

Other (Please describe)

40. What is your relationship status?

Married

Widowed

Divorced

Separated

Single

Member of a partnered couple

Other

41. What is the highest level of education you have completed?

Some high school

High school graduate

Some college

College graduate

Trade, technical, or vocational school

Some postgraduate work

Postgraduate degree

42. What is your annual household income?

Less than $\$ 25,000$

Between $\$ 25,000$ and $\$ 50,000$

Between $\$ 50,000$ and $\$ 75,000$

Between $\$ 75,000$ and $\$ 100,000$

More than $\$ 100,000$

Powered by Qualtrics 